\title{
Vitamin D deficiency and anemia is highly prevalent and dependent on the etiology of heart failure: A pilot study
}

\author{
Jolanta Małyszko ${ }^{1}$, Anna Tomaszuk-Kazberuk ${ }^{2}$, Konrad Dobrzycki ${ }^{3}$, \\ Hanna Bachórzewska-Gajewska ${ }^{3,4}$, Marcin Zorawski ${ }^{4}$, \\ Ewa Koc-Zorawska ${ }^{5}$, Grażyna Kobus ${ }^{4}$, Sławomir Dobrzycki ${ }^{3}$ \\ ${ }^{1}$ Department of Nephrology, Dialysis and Internal Medicine, \\ Warsaw Medical University, Warsaw, Poland \\ ${ }^{2}$ Department of Cardiology, Medical University of Bialystok, Poland \\ ${ }^{3}$ Department of Invasive Cardiology, Medical University of Bialystok, Poland \\ ${ }^{4}$ Department of Clinical Medicine, Medical University of Bialystok, Poland \\ ${ }^{5} 2^{\text {nd }}$ Department of Nephrology and Hypertension, Medical University of Bialystok, Poland
}

\begin{abstract}
Background: Anemia and vitamin D deficiency are common factors in chronic heart failure (CHF). The aim of this study was to assess vitamin D levels as well as its binding protein and anemia in relation to a cause of CHF: coronary heart disease, valvular disease and cardiomyopathy.

Methods: One hundred and sixteen consecutive patients (36 females and 80 males) with CHF were admitted for percutaneous coronary interventions (PCI). Hemoglobin concentration, serum creatinine, B-type natriuretic peptide (BNP), 25-hydroxyvitamin D [25(OH)D] and its binding protein-VDBP were measured.

Results: The prevalence of anemia was $22 \%$. BNP was the highest in the group with coronary artery disease. Ejection fraction was the lowest in cardiomyopathy group. 25(OH)D was lowest in valvular disease group, significantly lower than in the coronary artery group. A similar pattern of change showed vitamin D binding protein. The prevalence of vitamin D deficiency (level below $20 \mathrm{ng} / \mathrm{mL}$ ) in the whole group was $95 \%$, in $49 \%$ of the patients $25(\mathrm{OH}) \mathrm{D}$ was below $10 \mathrm{ng} / \mathrm{mL}$. In univariate analysis $25(\mathrm{OH}) \mathrm{D}$ correlated with hemoglobin, red blood cell count, hematocrit, mean corpuscular volume and BNP in patients with CHF in the whole group. In multiple regression analysis, predictors of 25(OH)D were estimated, glomerular filtration rate, BNP and valvular disease.

Conclusions: 25(OH)D deficiency is common in CHF patients. Valvular disease is associated the most severe vitamin $D$ deficiency and worsened kidney function. A higher prevalence of anemia in CHF due to coronary heart disease may be associated with wider use of angiotensin converting enzyme inhibitors and acetylsalicylic acid. Heart and kidney function are predictors of $25(\mathrm{OH}) \mathrm{D}$ level in the patients of this study. (Cardiol J 2021; 28, 2: 262-270)
\end{abstract}

Key words: vitamin D deficiency, anemia, heart failure

Address for correspondence: Anna Tomaszuk-Kazberuk, MD, PhD, Department of Cardiology, Medical University of Bialystok, ul. M. Skłodowskiej-Curie 24A, 15-276 Białystok, Poland, tel: +48 85746 86 56, tel: +48 600044 992, fax: +48 8574686 04, e-mail: a.tomaszuk@poczta.fm

Received: 12.09.2018 Accepted: 6.01.2019

This article is available in open access under Creative Common Attribution-Non-Commercial-No Derivatives 4.0 International (CC BY-NC-ND 4.0) license, allowing to download articles and share them with others as long as they credit the authors and the publisher, but without permission to change them in any way or use them commercially. 


\section{Introduction}

Heart failure (HF) is a common clinical syndrome caused by a variety of cardiac diseases [1]. $\mathrm{HF}$ prevalence has been increasing recently due to an aging population and prolongation of life by modern therapeutic innovations. Despite improvements in therapy, the mortality rate in patients with $\mathrm{HF}$ has remained unacceptably high [1]. In the 1970s, hypertension and coronary disease, particularly myocardial infarction (MI), were the primary causes of HF in the United States and Europe [1-3]. However, coronary artery disease (CAD) and diabetes mellitus have become increasingly responsible for $\mathrm{HF}$ while hypertension and valve disease have become less common because of improvements in diagnosis and therapy [4-7]. Risk factors for HF include coronary heart disease, cigarette smoking, hypertension, obesity, diabetes, and valvular heart disease $[5,8]$. Vitamin D deficiency and anemia are frequent findings in HF [1-4]. It was previously shown that the prevalence of anemia in a cohort undergoing percutaneous coronary intervention (PCI) was $21 \%$ and related to the New York Heart Association (NYHA) class [9].

Taking all these data into consideration, including fact that studies on anemia and 25-hydroxyvitamin D [25(OH)D] in HF are scarce and equivocal, this cross-sectional study was designed to investigate: a) the prevalence of anemia and vitamin $\mathrm{D}$ deficiency in patients with $\mathrm{HF}$ due to $\mathrm{CAD}$, cardiomyopathy or valvular disease undergoing PCIs; $b$ ) relation between $25(\mathrm{OH}) \mathrm{D}$, its binding protein and anemia in these three subpopulations.

\section{Methods}

The study was performed on 116 consecutive patients: 36 females and 80 males with chronic HF with reduced ejection fraction admitted to the Department of Invasive Cardiology for PCIs. The criteria for patients with HF to be included in the study were according to the European Society of Cardiology (ESC) guidelines from 2016 [10]: 1) age $\geq 18$ years; 2 ) documented history of $\mathrm{HF}$ of $\geq 6$ months; 3 ) left ventricular ejection fraction (LVEF) $\leq 40 \%$ as assessed by echocardiography (performed at the beginning of the study, using the Simpson planimetric method); 4) clinical stability and unchanged medications for $\geq 1$ month prior to the study. Patients were divided into three subgroups: group I - patients with chronic $\mathrm{HF}$ due to CAD $(n=40)$; group II - patients with HF due to cardiomyopathy $(\mathrm{n}=31)$; and group III — patients with $\mathrm{HF}$ due to valvular disease without signs or symptoms of CAD $(n=45)$.

Exclusion criteria included: 1) acute coronary syndrome or coronary revascularization within 3 months before the study; 2) unplanned hospitalization due to HF deterioration or any other cardiovascular reason within 1 month before the study; 3) any acute or chronic illness that might influence iron metabolism (including malignancy, infection, chronic kidney disease [CKD] requiring renal replacement therapy, and hematological diseases); 4) any anemia and/or iron deficiency treatment either at the beginning or during 12 months prior to the study. The study protocol was approved by the local ethics committee and all subjects gave informed written consent. The study was conducted in accordance with the Declaration of Helsinki. In all patients, venous blood samples were taken in the morning following an overnight fast and after lying supine at rest for at least $15 \mathrm{~min}$. Hematological parameters were assessed from fresh venous blood sampled with ethylenediaminetetraacetic acid (EDTA). Biochemical parameters were assessed in clotted samples. After centrifuging, serum was collected and frozen at $-80^{\circ} \mathrm{C}$ until laboratory analysis.

The following blood biomarkers were measured directly: hemoglobin concentration, serum creatinine, B-type natriuretic peptide (BNP) were assayed by standard laboratory methods in the central laboratory at the University Hospital. Estimated glomerular filtration rate (eGFR) was assessed using Chronic Kidney Disease Epidemiology Collaboration equation (CKD-EPI) [11]. Creatinine clearance was estimated using the Cockcroft-Gault formula (creatinine clearance $=(140-$ age $) \times$ body weight $/$ serum creatinine $\times 72$ if female $\times 0.85)[12] .25(\mathrm{OH}) \mathrm{D}$ was assayed using commercially available kits from Gentaur, Kampenhout, Belgium and its binding protein (VDBP) using assays from R\&D, Minneapolis, MN, USA. Kidney function was assessed either by serum creatinine or creatinine clearance according to CockcroftGault formula.

Anemia was defined according to the World Health Organization (WHO) criteria, i.e., hemoglobin below $12 \mathrm{~g} / \mathrm{dL}$ in females and $13 \mathrm{~g} / \mathrm{dL}$ in males [13]. According to the WHO, vitamin D insufficiency is defined as serum $25(\mathrm{OH}) \mathrm{D}$ below $20 \mathrm{ng} / \mathrm{mL}$ (50 nmoL/L) [14]. However, Holick [15] defined vitamin $\mathrm{D}$ deficiency as serum $25(\mathrm{OH}) \mathrm{D}$ level below $20 \mathrm{ng} / \mathrm{mL}$ and vitamin D insufficiency as less than $30 \mathrm{ng} / \mathrm{mL}$ (75 nmoL/L). The rationale to change the definition was based on the finding that serum 
parathyroid hormone, which correlated negatively with serum $25(\mathrm{OH}) \mathrm{D}$, declined as serum $25(\mathrm{OH}) \mathrm{D}$ raised and achieved a plateau at a serum $25(\mathrm{OH}) \mathrm{D}$ of approximately $30 \mathrm{ng} / \mathrm{mL}(75 \mathrm{nmoL} / \mathrm{L})[16,17]$.

\section{Statistical analysis}

The statistical significance of differences between the groups was tested using either analysis of variance with F statistics, the Student $t$ test, or $\chi^{2}$ test, where appropriate. The associations between variables were assessed using the univariate Pearson correlation coefficients or the Spearman rank correlation coefficients. A value of $p<0.05$ was considered statistically significant. The multiple regression analysis was used to determine independent factors affecting the dependent variables. Factors showing linear correlation with $25(\mathrm{OH}) \mathrm{D}$ $(\mathrm{p}<0.1)$ were included in the analysis. All statistical analyses were performed using Statistica 13.1.

\section{Results}

According to the definition, the prevalence of anemia in the studied cohort was $22 \%$ (18\% in females and $25 \%$ in males). In NYHA class I prevalence of anemia was $11 \%$, in class II $-22 \%$, in class III $-23 \%$, and $31 \%$ in class IV ( $p<0.01$ for trend). Baseline clinical and biochemical characteristics of the population studied is presented in Table 1. The group with cardiomyopathy was significantly younger than the two other groups. The degree of $\mathrm{HF}$ is reflected by NYHA class (median value was 2 in all groups) and did not differ between groups studied, however BNP was the highest in the group with CAD and LVEF was the lowest in the cardiomyopathy group. Kidney function assessed either by serum creatinine or creatinine clearance according to the Cockcroft-Gault formula, which included body weight, which were similar, whereas eGFR was significantly higher in the cardiomyopathy group when compared to the valvular disease group. $25(\mathrm{OH}) \mathrm{D}$ was lowest in valvular disease and cardiomyopathy group, significantly lower than in the coronary artery group. VDBP was significantly lower in group III relative to group I. When the definition of Holick was adopted [15], the prevalence of vitamin D deficiency in the whole group was $95 \%$, only 6 patients had vitamin levels higher than $20 \mathrm{ng} / \mathrm{mL}$, all of them in group I. Serum $25(\mathrm{OH}) \mathrm{D}$ below $10 \mathrm{ng} / \mathrm{mL}$ was found in $49 \%$ of the patients studied, $40 \%$ in group I, $45 \%$ in group II and $60 \%$ in group III, respectively. When patients were classified as anemic/non-anemic it was found that in group I, serum iron was lower in anemic relative to non-anemic patients ( $39 \pm 17$ vs. $80 \pm$ $\pm 33 \mu \mathrm{g} / \mathrm{dL}, \mathrm{p}<0.01$ ), as well as eGFR by CKD-EPI $\left(69 \pm 33\right.$ vs. $\left.86 \pm 31 \mathrm{~mL} / \mathrm{min} / 1.73 \mathrm{~m}^{2}, \mathrm{p}<0.05\right)$. In group II in anemic patients eGFR by CKD-EPI was lower relative to non-anemic patients $(69 \pm 33$ vs. $93 \pm 37 \mathrm{~mL} / \mathrm{min} / 1.73 \mathrm{~m}^{2}, \mathrm{p}<0.05$ ). In group III, NYHA class was higher in anemic patients when compared to their non-anemic counterparts $(3 \pm 1$ vs. $2 \pm 0.5, \mathrm{p}<0.05)$. In univariate analysis vitamin D correlated with hemoglobin $(r=0.61$, $\mathrm{p}<0.01$; Fig. 1), red blood cell count $(r=0.42$, $\mathrm{p}<0.05)$, hematocrit $(\mathrm{r}=0.44, \mathrm{p}<0.01)$, mean corpuscular volume (MCV; $\mathrm{r}=0.25, \mathrm{p}<0.05)$ and BNP ( $r=0.30, p<0.01$; Fig. 2$)$ in patients with $\mathrm{HF}$ (in the whole group). Vitamin $\mathrm{D}$ binding protein was related to age $(r=0.21, \mathrm{p}<0.05$; Fig. 3$)$. In the multivariable-adjusted logistic regression analyses on the etiology of $\mathrm{HF}$, predictors of $25(\mathrm{OH}) \mathrm{D}$ were eGFR $(\mathrm{r}=0.38, \mathrm{p}=0.004)$, BNP $(\mathrm{r}=0.41, \mathrm{p}=0.003)$ and valvular etiology $(\mathrm{r}=0.29$, $\mathrm{p}=0.005)$, adjusted $\mathrm{R}^{2}$ was $45 \%, \mathrm{~F}(4,53)$, $\mathrm{p}<0.001, \mathrm{SE}=6.82$.

\section{Discussion}

In the present study, $25(\mathrm{OH}) \mathrm{D}$ concentration was assessed together with its binding protein in patients with $\mathrm{HF}$ referred for coronary angiography. The main finding in the current study was a high prevalence of vitamin D deficiency (almost 100\% in the whole group) and an especially profound vitamin $\mathrm{D}$ deficiency $(<10 \mathrm{ng} / \mathrm{mL})$ in HF patients. $25(\mathrm{OH}) \mathrm{D}$ was lowest in patients with HF due to valvular disease, significantly lower than in patients with CAD. In the present study, all patients had 25(OH)D lower than $30 \mathrm{ng} / \mathrm{mL}$. Almost $50 \%$ of the population studied had $25(\mathrm{OH}) \mathrm{D}$ lower than $10 \mathrm{ng} / \mathrm{mL}$. It was also found that VDBP was lowest in the valvular disease group relative to the coronary artery group. Measurements were done in the winter time. $25(\mathrm{OH}) \mathrm{D}$ levels in 24 heathy age and sex matched volunteers were also assessed and it was found that 8 of them had 25(OH)D levels below $20 \mathrm{ng} / \mathrm{mL}$, but higher than $10 \mathrm{ng} / \mathrm{mL}$. Mean level was $22 \pm 7 \mathrm{ng} / \mathrm{mL}$, and the VDBP level was $337 \pm 55 \mu \mathrm{g} / \mathrm{mL}$. It was highly significant, above $(\mathrm{p}<0.001)$ than in the studied population. As reported in the literature, the bone-centric guidelines recommend a target $25(\mathrm{OH}) \mathrm{D}$ concentration of $20 \mathrm{ng} / \mathrm{mL}$ ( $50 \mathrm{nmol} / \mathrm{L}$ ), and age-dependent daily vitamin D doses of 400-800 IU. The guidelines focused on pleiotropic effects of vitamin $\mathrm{D}$ recommend a target $25(\mathrm{OH}) \mathrm{D}$ concentration of $30 \mathrm{ng} / \mathrm{mL}$ (75 nmol/L), and age, body weight, disease status, 
Table 1. Clinical and biochemical characteristics of groups studied.

\begin{tabular}{|c|c|c|c|c|}
\hline & $\begin{array}{c}\text { Group I } \\
\text { Coronary } \\
\text { heart disease }\end{array}$ & $\begin{array}{l}\text { Group II } \\
\text { Cardio- } \\
\text { myopathy }\end{array}$ & $\begin{array}{l}\text { Group III } \\
\text { Valvular } \\
\text { disease }\end{array}$ & $\mathbf{P}$ \\
\hline Age [years] & $68 \pm 11$ & $61 \pm 10$ & $67 \pm 10$ & $\begin{array}{l}\text { I vs. II: } p<0.01 \\
\text { II vs. III: } p<0.01\end{array}$ \\
\hline Anemic patients & $29 \%$ & $20 \%$ & $21 \%$ & I vs. II: $p<0.05$ \\
\hline Hemoglobin $[\mathrm{g} / \mathrm{dL}]$ & $13 \pm 12$ & $14 \pm 2$ & $13 \pm 2$ & NS \\
\hline Hematocrit [\%] & $40 \pm 5$ & $42 \pm 5$ & $40 \pm 5$ & NS \\
\hline Erythrocyte count $\left[\times 10^{12} / \mu \mathrm{L}\right]$ & $4.5 \pm 0.5$ & $4.7 \pm 0.5$ & $4.5 \pm 0.6$ & NS \\
\hline $\mathrm{MCV}[\mathrm{fL}]$ & $89 \pm 5$ & $90 \pm 5$ & $89 \pm 4$ & NS \\
\hline Iron $[\mu \mathrm{g} / \mathrm{dL}]$ & $65 \pm 33$ & $88 \pm 33$ & $89 \pm 44$ & $\begin{array}{l}\text { I vs. II: } p<0.01 \\
\text { I vs. III: } p<0.001\end{array}$ \\
\hline Ferritin $[\mathrm{ng} / \mathrm{mL}]$ & $167(79 ; 246)$ & $175(113 ; 276)$ & $115(75 ; 193)$ & II vs. III: $p<0.05$ \\
\hline Transferrin saturation [\%] & $23 \pm 12$ & $29 \pm 13$ & $28 \pm 14$ & $\begin{array}{l}\text { I vs. II: } p<0.05 \\
\text { I vs. III: } p<0.05\end{array}$ \\
\hline Functional iron deficiency & $7 \%$ & $8 \%$ & $11 \%$ & NS \\
\hline Absolute iron deficiency & $5 \%$ & $6 \%$ & $9 \%$ & NS \\
\hline Vitamin $D[\mathrm{ng} / \mathrm{mL}]$ & $13 \pm 6$ & $10 \pm 5$ & $10 \pm 3$ & $\begin{array}{l}\text { I vs. II: } p<0.05 \\
\text { I vs. III: } p<0.05\end{array}$ \\
\hline Vitamin $D$ binding protein $[\mu \mathrm{g} / \mathrm{mL}]$ & $281 \pm 106$ & $262 \pm 51$ & $245 \pm 81$ & I vs. III: $p<0.05$ \\
\hline Vitamin D deficiency & $85 \%$ & $100 \%$ & $100 \%$ & $\begin{array}{l}\text { I vs. II: } p<0.05 \\
\text { I vs. III: } p<0.05\end{array}$ \\
\hline Creatinine $[\mathrm{mg} / \mathrm{dL}]$ & $1.0 \pm 0.3$ & $1.0 \pm 0.2$ & $1.0 \pm 0.3$ & NS \\
\hline Creatinine clearance $[\mathrm{mL} / \mathrm{min}]$ & $70 \pm 22$ & $72 \pm 21$ & $67 \pm 17$ & NS \\
\hline eGFR by CKD-EPI $\left[\mathrm{mL} / \mathrm{min} / 1.72 \mathrm{~m}^{2}\right]$ & $81 \pm 31$ & $88 \pm 34$ & $71 \pm 21$ & II vs. III: $p<0.05$ \\
\hline CKD prevalence & $27 \%$ & $30 \%$ & $25 \%$ & NS \\
\hline Ejection fraction [\%] & $29 \pm 8$ & $24 \pm 7$ & $40 \pm 16$ & $\begin{array}{l}\text { I vs. II: } p<0.05 \\
\text { I vs. III: } p<0.01 \\
\text { II vs. III: } p<0.01\end{array}$ \\
\hline $\mathrm{BNP}[\mathrm{pg} / \mathrm{mL}]$ & $328(210 ; 723)$ & $263(125 ; 599)$ & $227(81 ; 466)$ & I vs. III: $p<0.05$ \\
\hline Hypertension & $61 \%$ & $57 \%$ & $61 \%$ & NS \\
\hline Diabetes & $32 \%$ & $19 \%$ & $28 \%$ & NS \\
\hline Atrial fibrillation & $23 \%$ & $33 \%$ & $38 \%$ & NS \\
\hline ACEI & $94 \%$ & $97 \%$ & $76 \%$ & $\begin{array}{l}\text { I vs. III: } p<0.001 \\
\text { II vs. III: } p<0.001\end{array}$ \\
\hline ASA & $94 \%$ & $64 \%$ & $55 \%$ & $\begin{array}{l}\text { I vs. II: } p<0.001 \\
\text { I vs. III: } p<0.001\end{array}$ \\
\hline Thienopyridines & $60 \%$ & $24 \%$ & $22 \%$ & $\begin{array}{l}\text { I vs. II: } p<0.001 \\
\text { I vs. III: } p<0.001\end{array}$ \\
\hline Anticoagulants & $11 \%$ & $33 \%$ & $31 \%$ & $\begin{array}{l}\text { I vs. II: } p<0.01 \\
\text { I vs. III: } p<0.001\end{array}$ \\
\hline Diuretics & $79 \%$ & $87 \%$ & $67 \%$ & $\begin{array}{l}\text { I vs. III: } p<0.05 \\
\text { II vs. III: } p<0.001\end{array}$ \\
\hline
\end{tabular}

Data given are percentages, means \pm standard deviation or median and interquartile ranges. ACEI - angiotensin converting enzyme inhibitors; ASA - acetylsalicylic acid; BNP - B-type natriuretic peptide; CKD - chronic kidney diseaese; CKD-EPI - Chronic Kidney Disease Epidemiology Collaboration equation; eGFR - estimated glomerular filtration rate; MCV — mean corpuscular volume

and ethnicity-dependent vitamin $\mathrm{D}$ doses ranging between 400 and $2000 \mathrm{IU} /$ day $[18,19]$.

Kolaszko et al. [20] assessed 25(OH)D levels in patients hospitalized in the cardiology ward with regard to a presence or absence of HF. It was found that these groups did not differ with regard to $25(\mathrm{OH}) \mathrm{D}$ levels. In addition, $25(\mathrm{OH}) \mathrm{D}$ levels were similar in patients with or without CAD, 


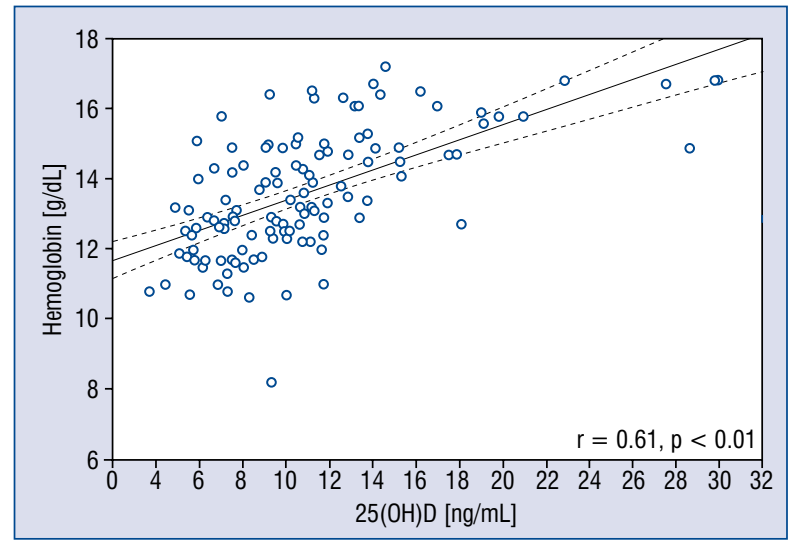

Figure 1. Correlation between hemoglobin and $25(\mathrm{OH}) \mathrm{D}$ in heart failure patients.

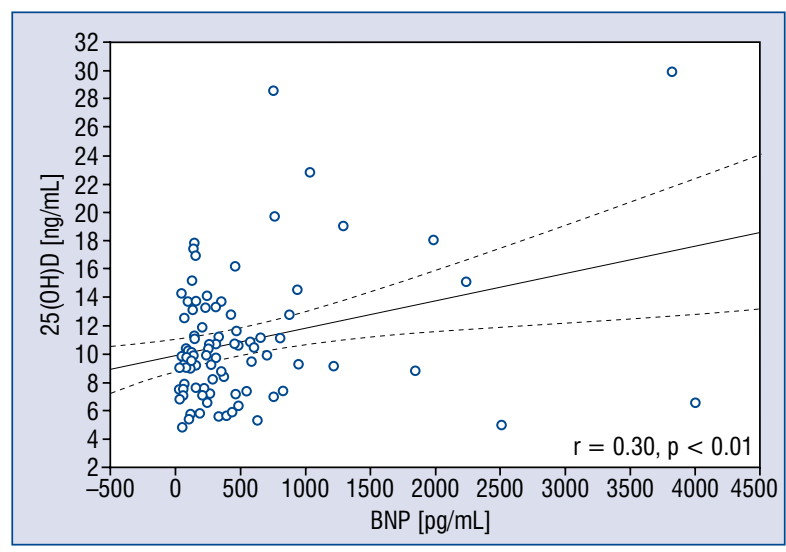

Figure 2. Correlation between B-type natriuretic peptide $(\mathrm{BNP})$ and $25(\mathrm{OH}) \mathrm{D}$ in heart failure patients.

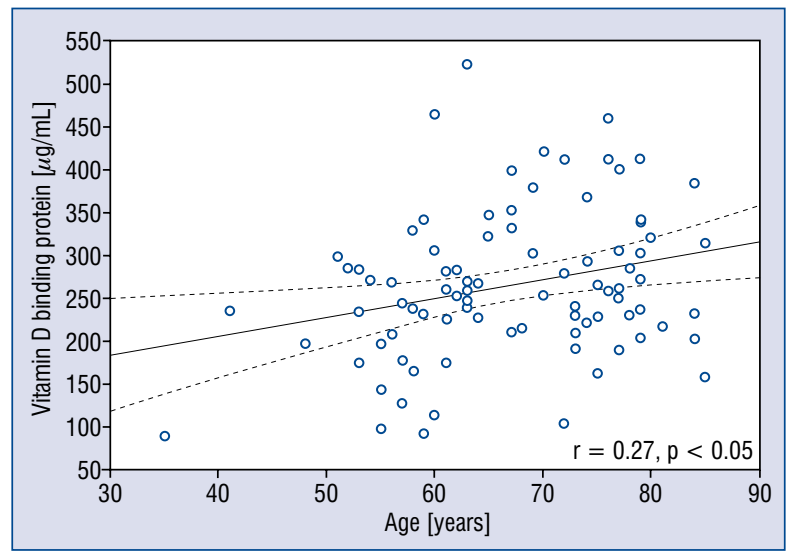

Figure 3. Correlation between vitamin $D$ binding protein and age in heart failure patients. however, the prevalence of vitamin D deficiency or insufficiency was not reported. The mean level of $25(\mathrm{OH}) \mathrm{D}$ in the present study was $12 \pm 5 \mathrm{ng} / \mathrm{mL}$ in $\mathrm{HF}$ and samples were taken in the winter time, similar to the paper by Kolaszko et al. [20]. Being fully aware of seasonal variations [21] data was not collected on dietary supplements of vitamins and other nutrients as well as medications affecting bone health (i.e. steroids). The population herein was slightly older than those studied by Kolaszko et al. [20]. Moreover, 25( $\mathrm{OH}) \mathrm{D}$ was assessed and its binding protein in $\mathrm{HF}$ patients of three different etiologies, while in previous studies etiology was not taken into account. Renal function as reflected by eGFR was comparable to the Kolaszko et al. [20] study. Polat et al. [22] reported that lowered 25(OH)D concentration in HF due to cardiomyopathy was related to severity of the disease. In the present study, there was no correlation between LVEF and 25(OH)D in any group studied.

In the Pandey et al. [23] study more than $90 \%$ of HF patients with preserved ejection fraction had $25(\mathrm{OH}) \mathrm{D}$ insufficiency, and $30 \%$ were deficient. It was also associated with exercise intolerance as reflected by lower peak $\mathrm{VO}_{2}$ and 6 -minute walk distance in $\mathrm{HF}$ with preserved ejection fraction. Saponaro et al. [24] evaluated the levels of vitamin D in patients with HF and were compared to a control group to assess the effects of vitamin $\mathrm{D}$ on HF outcome. They reported that patients with HF had statistically lower $25(\mathrm{OH}) \mathrm{D}$ levels $(\mathrm{p}<0.001)$ and a statistically higher prevalence of vitamin $\mathrm{D}$ insufficiency $(61.1 \%$ vs. $39.5 \%, \mathrm{p}<0.001)$ and deficiency $(24.7 \%$ vs. $6.6 \%, \mathrm{p}<0.001)$, relative to the healthy controls. In addition, a significant inverse relationship was observed between baseline $25(\mathrm{OH}) \mathrm{D}$ and risk of HF-related death, having a hazard ratio of 0.59 (95\% confidence interval $0.37-0.92, p=0.02$ ), and was confirmed in a multivariate adjusted analysis. In corroboration with this study, Walker et al. [25] in a prospective cohort study of 1802 patients with chronic HF and LVEF $\leq 45 \%$ found that sepsis was the major cause of death in their study. As sepsis death was independently associated with lower log serum vitamin D than non-sepsis death, and vitamin D supplementation was suggested to possibly be one of the targeted preventative strategies.

Pludowski et al. [26] evaluated the 25(OH)D concentration in a representative group of 5775 adult volunteers in 22 Polish cities. Conducted 
in late winter, mean and median concentration of $25(\mathrm{OH}) \mathrm{D}$ were $18 \pm 10 \mathrm{ng} / \mathrm{mL}$ and $16 \mathrm{ng} / \mathrm{mL}$, respectively. In the whole group (spring and winter measurements) serum 25(OH)D levels lower than $20 \mathrm{ng} / \mathrm{mL}$ were found in $66 \%$. Also reported, $16 \%$ of the participants had surprisingly low levels of $25(\mathrm{OH}) \mathrm{D}$ i.e. below $10 \mathrm{ng} / \mathrm{mL}$. In the current study, $49 \%$ of the participants had $25(\mathrm{OH}) \mathrm{D}$ lower than $10 \mathrm{ng} / \mathrm{mL}$. In the study performed in northern Poland on 448 adults from February to mid-April, the mean $25(\mathrm{OH}) \mathrm{D}$ level was $14 \pm 7 \mathrm{ng} / \mathrm{mL}$ years and $84 \%$ had a concentration of less than $20 \mathrm{ng} / \mathrm{mL}(<50$ $\mathrm{nmol} / \mathrm{L}$ ) [27]. Similar data came from a study on 274 elderly (mean age 69 years) postmenopausal women living in Warsaw [28]. The mean 25(OH)D level was $14 \mathrm{ng} / \mathrm{mL}$ (winter time) and $83 \%$ had $25(\mathrm{OH}) \mathrm{D}$ deficiency. A debate continues on the lower limit of normal for 25(OH)D levels, which depends upon geographic location and sunlight exposure of the reference population. Moreover, there is no consensus on optimal $25(\mathrm{OH}) \mathrm{D}$ concentration for skeletal or extraskeletal health. The Institute of Medicine concluded that a serum $25(\mathrm{OH}) \mathrm{D}$ concentration of $20 \mathrm{ng} / \mathrm{mL}(50 \mathrm{nmol} / \mathrm{L})$ is sufficient for most individuals [29], but other experts (Endocrine Society, National Osteoporosis Foundation [NOF], International Osteoporosis Foundation [IOF], American Geriatrics Society [AGS]) suggest that a minimum level of $30 \mathrm{ng} / \mathrm{mL}$ $(75 \mathrm{nmol} / \mathrm{L})$ is necessary in older adults to minimize the risk of falls and fractures [30-32]. Zhang et al. [33]. reported a plateau above $20 \mathrm{ng} / \mathrm{mL}$ for incidence, but much higher for mortality. In the Moli-sani study vitamin D deficiency was associated, independently of known HF risk factors, with an increased risk of hospitalization for $\mathrm{HF}$ in an Italian adult population [34].

In the present study, a vast majority of patients had vitamin D deficiency, could not be solely ascribed to impaired kidney function. Other causes of $25(\mathrm{OH}) \mathrm{D}$ deficiency include: decreased intake or absorption, reduced sun exposure, increased hepatic catabolism, decreased endogenous synthesis (via decreased 25-hydroxylation in the liver or 1-hydroxylation in the kidney), or end-organ resistance to $25(\mathrm{OH}) \mathrm{D}$. Winter levels of $25(\mathrm{OH}) \mathrm{D}$ mainly depend on food intake and previous liver storage. Dietary assessment was not performed in the present population studied. As cutaneous vitamin $\mathrm{D}$ production and vitamin $\mathrm{D}$ stores decline with age [35], this explanation may also be considered, at least partially. In addition to reduced endogenous production, vitamin $\mathrm{D}$ intake is often low in older subjects. It has been also reported that in hospital- ized patients, 25(OH)D deficiency defined as level $<15 \mathrm{ng} / \mathrm{mL}$ ) was found in $57 \%$, of whom $22 \%$ were considered severely deficient (serum concentration of $25(\mathrm{OH}) \mathrm{D}<8 \mathrm{ng} / \mathrm{mL}$ ) [36]. As shown, predictors of vitamin $D$ deficiency were inadequate vitamin $D$ intake, winter season, and housebound status. As vitamin $\mathrm{D}$ deficiency may be dependent, in part, upon the age of patients on hospital wards [37,38], it should be stressed that in a subgroup of patients $<65$ years without known risk factors, vitamin D deficiency was still detected in $42 \%$ [35] of them. As it has been reported previously [39], vitamin D deficiency predisposes up-regulation of renin-angiotensin-aldosterone (RAA) system, causes left ventricle hypertrophy and vascular smooth muscle cell hypertrophy as well.

Anemia was found in $22 \%$ of patients studied. Its prevalence rose significantly with NYHA class (from $11 \%$ in class I to $31 \%$ in class IV). A subclinical inflammatory state was reported, as reflected by elevated levels of cytokines, hemodilution, dietary deficiencies including iron and other microelements, the use of medications affecting RAA system, CKD, poor nutrition and decreased bone marrow perfusion may all contribute to the development of anemia in HF [40-42]. Inflammatory cytokines or high sensitivity C-reactive protein were not studied in the present patients, however, CKD was present in $25-30 \%$ of patients as well as iron deficiency (both absolute and functional) was diagnosed in $12-20 \%$ depending on the HF etiology, in addition a vast majority of the patients were treated with drugs affecting the RAA system, and as well as acetylsalicylic acid (ASA) and anticoagulants. Therefore, the high prevalence of anemia in the studied group appears to be multifactorial with an important role of CKD as a subclinical inflammatory state and iron deficiency. In addition, therapy of chronic HF with the RAA system blockade and use of other drugs potentially contributed as anticoagulant to the presence of anemia in this population. Higher prevalence of anemia of valvular origin of chronic HF might be associated with a higher prevalence of impaired kidney function as reflected by lower eGFR and creatinine clearance, higher prevalence of iron deficiency (both absolute and functional).

As reviewed previously, angiotensin converting enzyme inhibitors (ACEI)/angiotensin II receptor blockers (ARB) can decrease hemoglobin levels by $0.2-0.3 \mathrm{~g} / \mathrm{dL}$ [43]. ACEI declined vascular resistance in efferent arterioles in glomeruli, increased oxygenation in the peritubular region and thereby lowered the signal for synthesis of erythropoietin. 
The tetrapetide N-acetyl-Ser-Asp-Lys-Pro (Ac-SDKP) named goralatide or seraspenide, a normal inhibitor of entry for pluripotent cells into the S-phase, is metabolized by ACE. During therapy with ACEI, Ac-SDKP can accumulate and cause a decline in erythropoiesis [44].

Findings in the present study show a correlation between $25(\mathrm{OH}) \mathrm{D}$ and anemia in patients with HF. It may be due to the fact, that patients with worse kidney function and anemia had a lower $25(\mathrm{OH}) \mathrm{D}$. In other studies associations were found in patients scheduled for cardiac surgery and coronary angiography [45-47]. However, in the randomized controlled trials two studies reported no effect of vitamin $\mathrm{D}$ in anemia [48, 49], while two others performed in CKD showed a beneficial effect of vitamin $\mathrm{D}$ on the dose of erythropoietin stimulating agents [50, 51]. In Effect of Vitamin D on Mortality in Heart Failure (EVITA) trial vitamin $\mathrm{D}$ supplementation had no effect on anemia prevalence in advanced $\mathrm{HF}$ patients [52]. In the EVITA trial prevalence of anemia was $17 \%$ in the treatment group and $11 \%$ in the placebo group, whereas at termination of the study, the prevalence was much higher, reaching $32 \%$ in both groups. No data on iron status were provided. In the current study, prevalence of iron deficiency (absolute and functional) was close to $20 \%$. However, no correlations were found between iron parameters, $25(\mathrm{OH})$ $\mathrm{D}$ and its binding protein. It was assumed that there may simply be no causal relationship between anemia, iron status and 25(OH)D in HF. It is well established that vitamin $\mathrm{D}$ deficiency is highly prevalent in patients with CKD undergoing renal replacement therapy [53]. This supports the findings that kidney function was a predictor of $25(\mathrm{OH}) \mathrm{D}$ in $\mathrm{HF}$. As shown previously, prevalence of $\mathrm{CKD}$ was high in patients undergoing PCI despite normal serum creatinine, particularly in higher NYHA class [53, 54]. It corroborates with the present study that BNP was also a predictor of $25(\mathrm{OH}) \mathrm{D}$ in $\mathrm{HF}$ patients.

\section{Limitations of the study}

This study has several strengths and, on the other hand, several limitations. As all patients underwent coronary angiography, we were able to divide the cohort with regard to the etiology of HF. Moreover, vitamin D binding protein as well as detailed iron status data was also assessed. A limitation could be a lack of assessment of parathyroid hormone, calcium, phosphate and cross-sectional design. Other limitations include retrospective data analysis, and no advanced statistical approach to analyze independent associations.

\section{Conclusions}

Vitamin D deficiency is very common in HF patients, predominantly in valvular disease. Higher prevalence of anemia in HF due to CAD may be associated with wider ACEI and ASA use relative to other etiologies. Correlation between anemia and $25(\mathrm{OH}) \mathrm{D}$ are of interest but require further study to elucidate possible pathogenetic mechanism(s) and also do not provide a rationale for vitamin supplementation. However, heart and kidney function are predictors of $25(\mathrm{OH}) \mathrm{D}$ level.

\section{Acknowledgements}

This study was conducted with the use of equipment purchased by the Medical University of Białystok, Poland as part of the RPOWP 2007-2013 funding, Priority I, Axis 1.1, contract No. UDARPPD.01.01.00-20-001/15-00 dated 26.06.2015.

\section{Conflict of interest: None declared}

\section{References}

1. Ho KK, Pinsky JL, Kannel WB, et al. The epidemiology of heart failure: the Framingham Study. J Am Coll Cardiol. 1993; 22(4 Suppl A): 6A-613A, indexed in Pubmed: 8376698.

2. Levy D, Larson MG, Vasan RS, et al. The progression from hypertension to congestive heart failure. JAMA. 1996; 275(20): 1557-1562, indexed in Pubmed: 8622246.

3. Tomaszuk-Kazberuk A, Sobkowicz B, Kaminski K, et al. Myocardial perfusion assessed by contrast echocardiography correlates with angiographic perfusion parameters in patients with a first acute myocardial infarction successfully treated with angioplasty. Can J Cardiol. 2008; 24(8): 633-639, indexed in Pubmed: 18685744.

4. Kannel WB, Ho K, Thom T. Changing epidemiological features of cardiac failure. Br Heart J. 1994; 72(2 Suppl): S3-S9, indexed in Pubmed: 7946754.

5. He J, Ogden LG, Bazzano LA, et al. Risk factors for congestive heart failure in US men and women: NHANES I epidemiologic follow-up study. Arch Intern Med. 2001; 161(7): 996-1002, indexed in Pubmed: 11295963.

6. Gheorghiade M, Bonow RO. Chronic heart failure in the United States: a manifestation of coronary artery disease. Circulation. 1998; 97(3): 282-289, indexed in Pubmed: 9462531.

7. Michniewicz E, Mlodawska E, Lopatowska P, et al. Patients with atrial fibrillation and coronary artery disease - Double trouble. Adv Med Sci. 2018; 63(1): 30-35, doi: 10.1016/j.advms.2017.06.005, indexed in Pubmed: 28818746.

8. Baldasseroni S, Opasich C, Gorini M, et al. Left bundle-branch block is associated with increased 1-year sudden and total mortality rate in 5517 outpatients with congestive heart failure: a report from the Italian network on congestive heart failure. Am Heart J. 2002; 143(3): 398-405, indexed in Pubmed: 11868043.

9. Malyszko J, Bachorzewska-Gajewska H, Malyszko J, et al. Prevalence of chronic kidney disease and anemia in patients with coronary artery disease with normal serum creatinine undergo- 
ing percutaneous coronary interventions: relation to New York Heart Association class. Isr Med Assoc J. 2010; 12(8): 489-493, indexed in Pubmed: 21337818.

10. Ponikowski P, Voors AA, Anker SD, et al. Authors/Task Force Members, Document Reviewers. 2016 ESC Guidelines for the diagnosis and treatment of acute and chronic heart failure: The Task Force for the diagnosis and treatment of acute and chronic heart failure of the European Society of Cardiology (ESC). Developed with the special contribution of the Heart Failure Association (HFA) of the ESC. Eur J Heart Fail. 2016; 18(8): 891-975, doi:10.1002/ejhf.592, indexed in Pubmed: 27207191.

11. Stevens PE, Levin A. Kidney Disease: Improving Global Outcomes Chronic Kidney Disease Guideline Development Work Group Members. Evaluation and management of chronic kidney disease: synopsis of the kidney disease: improving global outcomes 2012 clinical practice guideline. Ann Intern Med. 2013; 158(11): 825-830, doi: 10.7326/0003-4819-158-11-20130604000007, indexed in Pubmed: 23732715.

12. Cockcroft DW, Gault MH. Prediction of creatinine clearance from serum creatinine. Nephron. 1976; 16(1): 31-41, doi: 10.1159/000180580, indexed in Pubmed: 1244564.

13. World Health Organization. Nutritional anaemias: Report of a WHO Scientific Group. World Health Organ Tech Rep Ser. 1968; 405: 5-37.

14. WHO Scientific Group on the Prevention and Management of Osteoporosis 2003 Prevention and management of osteoporosis: report of a WHO scientific group. Geneva: World Health Organization.

15. Holick MF. Vitamin D deficiency. N Engl J Med. 2007; 357(3): 266-281, doi: 10.1056/NEJMra070553, indexed in Pubmed: 17634462 .

16. http://books.nap.edu/openbook.php?record_id=13050 (Accessed on April 28, 2018).

16. Food and Nutrition Board of the Institute of Medicine. Vitamin D. In: Dietary reference intakes for calcium, hoshorus, magnesium, vitamin D, fluoride. National Academies Press, Washington, DC 1997: 250 .

17. Pludowski P, Holick MF, Grant WB, et al. Vitamin D supplementation guidelines. J Steroid Biochem Mol Biol. 2018; 175: 125-135, doi:10.1016/j.jsbmb.2017.01.021, indexed in Pubmed: 28216084.

18. Spedding S, Vanlint S, Morris H, et al. Does vitamin D sufficiency equate to a single serum 25-hydroxyvitamin D level or are different levels required for non-skeletal diseases? Nutrients. 2013; 5(12): 5127-5139, doi: 10.3390/nu5125127, indexed in Pubmed: 24352091.

19. Kolaszko A, Nowalany-Kozielska E, Ceranowicz P, et al. The Role of Parathyroid Hormone and Vitamin D Serum Concentrations in Patients with Cardiovascular Diseases. Dis Markers. 2018; 2018: 5287573, doi: $10.1155 / 2018 / 5287573$, indexed in Pubmed: 29599854.

20. Dopico XC, Evangelou M, Ferreira RC, et al. Widespread seasonal gene expression reveals annual differences in human immunity and physiology. Nat Commun. 2015; 6: 7000, doi: 10.1038/ ncomms8000, indexed in Pubmed: 25965853.

21. Polat V, Bozcali E, Uygun T, et al. Low vitamin D status associated with dilated cardiomyopathy. Int J Clin Exp Med. 2015; 8(1): 1356-1362, indexed in Pubmed: 25785137.

22. Pandey A, Kitzman DW, Houston DK, et al. Vitamin D Status and Exercise Capacity in Older Patients with Heart Failure with Preserved Ejection Fraction. Am J Med. 2018; 131(12): 1515. e11-1515.e19, doi: 10.1016/j.amjmed.2018.07.009, indexed in Pubmed: 30076811.
23. Saponaro F, Saba A, Frascarelli S, et al. Vitamin D measurement and effect on outcome in a cohort of patients with heart failure. Endocr Connect. 2018 [Epub ahead of print]; 7(9): 957-964, doi: 10.1530/EC-18-0207, indexed in Pubmed: 30049838.

24. Walker AMN, Drozd M, Hall M, et al. Prevalence and Predictors of Sepsis Death in Patients With Chronic Heart Failure and Reduced Left Ventricular Ejection Fraction. J Am Heart Assoc. 2018; 7(20): e009684, doi: 10.1161/JAHA.118.009684, indexed in Pubmed: 30371261.

25. Płudowski P, Ducki C, Konstantynowicz J, et al. Vitamin D status in Poland. Pol Arch Med Wewn. 2016; 126(7-8): 530-539, doi: 10.20452/pamw.3479, indexed in Pubmed: 27509842.

26. Kmieć P, Żmijewski M, Waszak P, et al. Vitamin D deficiency during winter months among an adult, predominantly urban, population in Northern Poland. Endokrynol Pol. 2014; 65(2): 105-113, doi: 10.5603/EP.2014.0015, indexed in Pubmed: 24802733.

27. Napiórkowska L, Budlewski T, Jakubas-Kwiatkowska W, et al. Prevalence of low serum vitamin D concentration in an urban population of elderly women in Poland. Pol Arch Med Wewn. 2009; 119(11): 699-703, indexed in Pubmed: 19920793.

28. Holick MF, Binkley NC, Bischoff-Ferrari HA, et al. Endocrine Society. Evaluation, treatment, and prevention of vitamin D deficiency: an Endocrine Society clinical practice guideline. J Clin Endocrinol Metab. 2011; 96(7): 1911-1930, doi: 10.1210/jc.20110385, indexed in Pubmed: 21646368.

29. Vieth R. What is the optimal vitamin D status for health? Prog Biophys Mol Biol. 2006; 92(1): 26-32, doi: 10.1016/j.pbiomolbio.2006.02.003, indexed in Pubmed: 16766239.

30. Dawson-Hughes B, Mithal A, Bonjour JP, et al. IOF position statement: vitamin D recommendations for older adults. Osteoporos Int. 2010; 21(7): 1151-1154, doi: 10.1007/s00198-0101285-3, indexed in Pubmed: 20422154.

31. American Geriatrics Society Workgroup on Vitamin D Supplementation for Older Adults. Recommendations abstracted from the American Geriatrics Society Consensus Statement on vitamin D for Prevention of Falls and Their Consequences. J Am Geriatr Soc. 2014; 62(1): 147-152, doi:10.1111/jgs.12631, indexed in Pubmed: 24350602.

32. Zhang R, Li B, Gao X, et al. Serum 25-hydroxyvitamin D and the risk of cardiovascular disease: dose-response meta-analysis of prospective studies. Am J Clin Nutr. 2017; 105(4): 810-819, doi: 10.3945/ajcn.116.140392, indexed in Pubmed: 28251933.

33. Costanzo S, De Curtis A, Di Castelnuovo A, et al. Moli-sani Study Investigators. Serum vitamin D deficiency and risk of hospitalization for heart failure: Prospective results from the Moli-sani study. Nutr Metab Cardiovasc Dis. 2018; 28(3): 298-307, doi: 10.1016/j.numecd.2017.11.008, indexed in Pubmed: 29331539.

34. Tsai KS, Wahner HW, Offord KP, et al. Effect of aging on vitamin D stores and bone density in women. Calcif Tissue Int. 1987; 40(5): 241-243, indexed in Pubmed: 3107776.

35. Thomas MK, Lloyd-Jones DM, Thadhani RI, et al. Hypovitaminosis D in medical inpatients. N Engl J Med. 1998; 338(12): 777-783, doi:10.1056/NEJM199803193381201, indexed in Pubmed: 9504937.

36. Perin A, Zanatta E, Pigatto E, et al. Hypovitaminosis D in an hospitalized old population of Western Friuli. Reumatismo. 2012; 64(3): 166-171, doi:10.4081/reumatismo.2012.166, indexed in Pubmed: 22842300 .

37. Ramel A, Jonsson PV, Bjornsson S, et al. Vitamin D deficiency and nutritional status in elderly hospitalized subjects in Iceland. Public Health Nutr. 2009; 12(7): 1001-1005, doi: 10.1017/ S1368980008004527, indexed in Pubmed: 19144240. 
38. Zittermann A. Vitamin D and disease prevention with special reference to cardiovascular disease. Prog Biophys Mol Biol. 2006; 92(1): 39-48, doi:10.1016/j.pbiomolbio.2006.02.001, indexed in Pubmed: 16600341.

39. Anand IS, Gupta P. Anemia and iron deficiency in heart failure: current concepts and emerging therapies. Circulation. 2018; 138(1): 80-98, doi:10.1161/CIRCULATIONAHA.118.030099, indexed in Pubmed: 29967232.

40. Sîrbu O, Floria M, Dascalita P, et al. Anemia in heart failure - from guidelines to controversies and challenges. Anatol J Cardiol. 2018; 20(1): 52-59, doi:10.14744/AnatolJCardiol.2018.08634, indexed in Pubmed: 29952364.

41. Tomaszuk-Kazberuk A, Bolińska S, Młodawska E, et al. Does admission anaemia still predict mortality six years after myocardial infarction? Kardiol Pol. 2014; 72(6): 488-493, doi: 10.5603/ KP.a2014.0046, indexed in Pubmed: 24526561.

42. Malyszko J, Oberbauer R, Watschinger B. Anemia and erythrocytosis in patients after kidney transplantation. Transpl Int. 2012; 25(10): 1013-1023, doi: 10.1111/j.1432-2277.2012.01513.x, indexed in Pubmed: 22716097.

43. Stigant CE, Cohen J, Vivera M, et al. ACE inhibitors and angiotensin II antagonists in renal transplantation: an analysis of safety and efficacy. Am J Kidney Dis. 2000; 35(1): 58-63, doi: 10.1016/ S0272-6386(00)70302-7, indexed in Pubmed: 10620545.

44. Ernst JB, Zittermann A, Pilz S, et al. Independent associations of vitamin $\mathrm{D}$ metabolites with anemia in patients referred to coronary angiography: the LURIC study. Eur J Nutr. 2017; 56(3): 1017-1024, doi: 10.1007/s00394-015-1149-x, indexed in Pubmed: 26746220

45. Ernst JB, Becker T, Kuhn J, et al. Independent association of circulating vitamin $\mathrm{D}$ metabolites with anemia risk in patients scheduled for cardiac surgery. PLoS One. 2015; 10(4): e0124751, doi: 10.1371/journal.pone.0124751, indexed in Pubmed: 25885271.

46. Zittermann A, Kuhn J, Dreier J, et al. Association of 25-hydroxyvitamin D with anemia risk in patients scheduled for car- diac surgery. Int J Lab Hematol. 2014; 36(1): 29-36, doi: 10.1111/ ijlh.12112, indexed in Pubmed: 23710993.

47. Sooragonda B, Bhadada SK, Shah VN, et al. Effect of vitamin D replacement on hemoglobin concentration in subjects with concurrent iron-deficiency anemia and vitamin D deficiency: a randomized, single-blinded, placebo-controlled trial. Acta Haematol. 2015; 133(1): 31-35, doi:10.1159/000357104, indexed in Pubmed: 25012612.

48. Madar AA, Stene LC, Meyer HE, et al. Effect of vitamin D3 supplementation on iron status: a randomized, double-blind, placebo-controlled trial among ethnic minorities living in Norway. Nutr J. 2016; 15(1): 74, doi: 10.1186/s12937-016-0192-7, indexed in Pubmed: 27506667.

49. Rianthavorn P, Boonyapapong P. Ergocalciferol decreases erythropoietin resistance in children with chronic kidney disease stage 5. Pediatr Nephrol. 2013; 28(8): 1261-1266, doi: 10.1007/s00467013-2431-x, indexed in Pubmed: 23420502.

50. Naini AE, Hedaiati ZP, Gholami D, et al. The effect of Vitamin $\mathrm{D}$ administration on treatment of anemia in end-stage renal disease patients with Vitamin D deficiency on hemodialysis: A placebo-controlled, double-blind clinical trial. J Res Med Sci. 2015; 20(8): 745-750, doi: 10.4103/1735-1995.168375, indexed in Pubmed: 26664421.

51. Ernst JB, Prokop S, Fuchs U, et al. Randomized supplementation of $4000 \mathrm{IU}$ vitamin $\mathrm{D}$ daily vs placebo on the prevalence of anemia in advanced heart failure: the EVITA trial. Nutr J. 2017; 16(1): 49, doi: 10.1186/s12937-017-0270-5, indexed in Pubmed: 28835271.

52. Malyszko J, Koc-Zorawska E, Kozminski P, et al. Underrecognition and Underestimation of Disturbances in Calcium-Phosphate Balance in Kidney Transplant Recipients. Transplant Proc. 2018; 50(6): 1790-1793, doi: 10.1016/j.transproceed.2018.02.155, indexed in Pubmed: 30056901.

53. Tomaszuk-Kazberuk A, Bachorzewska-Gajewska H, Malyszko J, et al. Impact of diabetes mellitus on survival in patients with end-stage renal disease: a three-year follow-up. Kidney Blood Press Res. 2011; 34(2): 83-86, doi: 10.1159/000323894, indexed in Pubmed: 21266825. 